\title{
Biogrout: A Novel Binding Material for Soil Improvement and Concrete Repair
}

\author{
Varenyam Achal ${ }^{1 *}$ and Satoru Kawasaki ${ }^{2}$ \\ 'Shanghai Key Lab for Urban Ecological Processes and Eco-Restoration, School of Ecological and Environmental Sciences, \\ East China Normal University, Shanghai, China, ${ }^{2}$ Faculty of Engineering, Hokkaido University, Sapporo, Japan
}

Keywords: grout, biogrout, calcite, soil improvement, concrete

\section{GROUT}

Grout is a binding agent or binder often used with building materials to improve their durability functions. It may be organic or inorganic material used for sealing or consolidation of cracks, pores, or voids in order to improve the mechanical properties and impermeability of a particular system, whether soil, cementitious or of other building materials. Grouts act as dispersion agents where dispersed particles form a network responsible for the effectiveness of grouting properties. Chemical grouts are the most common and well-known grouting materials used for sealing sand, soil, or other matrices. However, this is an expensive technique and it also affects the environment because chemical grouts based on acrylamides, lignosulfonates, and polyurethane are toxic and environmentally harmful. Thus, it is necessary to find new grouting materials and methods of injection. It is important to choose grouting materials that are soft and fine enough to penetrate into the discontinuities in voids, cracks, or cavities to fill them (Bras et al., 2013).

Hao Qi,

Edited by:

Tianjin University, China

Reviewed by:

Tianjin University, China
Hui Li,

\section{BIOGROUT}

East China University of Science and

Technology, China

*Correspondence:

Varenyam Achal

varenyam@re.ecnu.edu.cn

Specialty section:

This article was submitted to

Microbiotechnology, Ecotoxicology

and Bioremediation,

a section of the journal

Frontiers in Microbiology

Received: 24 November 2015

Accepted: 26 February 2016

Published: 17 March 2016

Citation:

Achal V and Kawasaki S (2016)

Biogrout: A Novel Binding Material for

Soil Improvement and Concrete

Repair. Front. Microbiol. 7:314.

doi: 10.3389/fmicb.2016.00314

On the other hand, various minerals including calcium carbonate, calcium phosphate, calcium oxalate, silicate, and iron oxide are precipitated in nature by living organisms (Mann, 1993). These biominerals are promising engineering materials because they provide adequate strength and low environmental impact. In order to reduce environmental impact and cost in the future, a novel grouting method that utilizes calcium carbonate precipitated by bacterial cells has been examined recently. Such grout is commonly called "biogrout," a product of biomineralization which has the potential to be a better alternate grouting material. A novel grout should have a self-leveling behavior in addition to a high compressive strength and low shrinkage, be easy to inject, and have good durability (Bras et al., 2013); this can be achieved using biogrout. Furthermore, as the microbial reaction in biogrout is slower than the chemical reaction in chemical grouts, this reduces the solidification speed, which allows the biogrout to spread through a greater volume of soil or other matrices (Akiyama and Kawasaki, 2012a,b).

Biogrouting technology is similar to chemical grouting where the depth of penetration depends on the size of bacteria used, in addition to the optimal conditions for bacterial activity such as $\mathrm{pH}$, salinity, oxidation-reduction potential, concentrations of nutrients, and content of water. Biogrout is calculated to be much cheaper than chemical grouting techniques. Raw materials increase the cost in chemical grouts ranging from $\$ 2$ to $72 \mathrm{per}^{3}$ of soil, compared to biogrouts in the range of $\$ 0.5$ to 9.0 per $\mathrm{m}^{3}$ of soil, in cases where waste materials are used as the source of carbon for bacterial growth (Ivanov and $\mathrm{Chu}, 2008$ ). 


\section{APPLICATION OF BIOGROUT}

Biogrout was successfully used to control ground permeability and to reinforce the ground with bacterially produced cementing materials (Whiffin et al., 2007; Ivanov and Chu, 2008; van Paassen et al., 2009; DeJong et al., 2010; Harkes et al., 2010). Most studies on biogrout development are mainly based on microbial induced calcite precipitation (MICP), a process involving ureolytic bacteria and urea as a substrate. During this process, bacterial urease hydrolyzes urea that increases the $\mathrm{pH}$ by producing ammonium ions and generates $\mathrm{CO}_{2}$. Furthermore, $\mathrm{CO}_{2}$ dissolution takes place and carbonate ions combine with calcium ions present in the proximal environment or on the cell wall of bacterial cells to precipitate calcium carbonate crystals (Li et al., 2015). These crystals create bridges between the sand grains, by which the soil is strengthened or cracks are sealed in the concrete. The precipitation of the solid calcium carbonate decreases the porosity and the permeability (van Wijngaarden et al., 2011). Furthermore, compared to cementitious soil or water saturated matrices, non-water saturated sandy soils such as sand dykes, road or train embankments, and sand dunes are hard to grout due to the decreased control of flow that can be exercised in the non-saturated soil environment. However, biogrout has resulted in homogeneous cementation over the entire length of a 1-m sand column, where calcite crystals provided strength related to the pore water content of the continuously drained column with less water content enabling more efficient strength formation (Cheng and Cord-Ruwisch, 2012). Scaled up experiments provided technical feasibility of BioGrout as a ground improvement method under real life conditions and with practical techniques, both as a single point injection or over a horizontal distance using screens of injection and extraction wells, where unconfined compressive strength (UCS) varied considerably from 0 to $12 \mathrm{MPa}$ (van Paassen et al., 2009). Such results open a way for biogrout to be applied in an open system in situ. Biogrout also plays an important role in sealing cracks in concrete, as bacterial cells grow in the presence of moisture, water, or oxygen, followed by urease production and ultimately calcite precipitation that seals cracks (Achal and Mukherjee, 2015).

\section{REFERENCES}

Achal, V., and Mukherjee, A. (2015). A review of microbial precipitation for sustainable construction. Constr. Build. Mater. 93, 1224-1235. doi: 10.1016/j.conbuildmat.2015.04.051

Akiyama, M., and Kawasaki, S. (2012a). Microbially mediated sand solidification using calcium phosphate compounds. Engin. Geol. 137-138, 29-39. doi: 10.1016/j.enggeo.2012.03.016

Akiyama, M., and Kawasaki, S. (2012b). Novel grout material comprised of calcium phosphate compounds: in vitro evaluation of crystal precipitation and strength reinforcement. Engin. Geol. 125, 119-128. doi: 10.1016/j.enggeo.2011.11.011

Bras, A., Gião, R., Lúcio, V., and Chastre, C. (2013). Development of an injectable grout for concrete repair and strengthening. Cem. Concr. Comp. 37, 185-195. doi: 10.1016/j.cemconcomp.2012.10.006

Cheng, L., and Cord-Ruwisch, R. (2012). In situ soil cementation with ureolytic bacteria by surface percolation. Ecol. Engin. 42, 64-72. doi: 10.1016/j.ecoleng.2012.01.013
Urease-based biogrout is commonly used by various researchers to improve mechanical properties, decrease the permeability of porous materials, repair cementitious materials, and modify the properties of soil, or sand (Whiffin et al., 2007; DeJong et al., 2010; Rong et al., 2012); however, this process suffers from excessive ammonia production. In order to solve this problem, recently biogrout was produced by an asparaginasebased MICP process, where MICP followed ammonification i.e., the process of amino acid deamination after hydrolysis of protein by heterotrophic bacteria as the $\mathrm{pH}$-increasing reaction (Galloway, 2005). Biogrout based on asparaginase resulted in UCS of $980 \mathrm{kPa}$ in sand compared to that of $1002 \mathrm{kPa}$ due to urease-based MICP process (Li et al., 2015).

\section{ADVANTAGE OF BIOGROUT}

The results suggest that there are possibilities to reduce the drawbacks of biogrout production such as reducing the effect of ammonia on the environment without compromising the mechanical and impermeable properties of biogrout in sand. The developed biogrouts have been shown to be economical, environmentally friendly, and that the rheological characteristics can be appropriate for injection applications to consolidate cracks in concrete and for soil improvement. We believe that biogrout will have a wider acceptance in future research and will attract more researchers to work on it.

\section{AUTHOR CONTRIBUTIONS}

All authors listed, have made substantial, direct and intellectual contribution to the work, and approved it for publication.

\section{ACKNOWLEDGMENTS}

The authors are thankful to the Japan Society for the Promotion of Science (JSPS) for providing an Invitation Fellowship Short-term FY2015 to VA to work on biogrout. VA also acknowledges the National Natural Science Foundation of China (41550110499) for providing funding to work in the area of MICP.

DeJong, J. T., Mortensen, B. M., Martinez, B. C., and Nelson, D. C. (2010). Bio-mediated soil improvement. Ecol. Engin. 36, 197-210. doi: 10.1016/j.ecoleng.2008.12.029

Galloway, J. N. (2005). “The global nitrogen cycle,” in Biogeochemistry, ed W. H. Schlesinger (Oxford: Elsevier-Pergamon), 557-583.

Harkes, M. P., Van Paassen, L. A., Booster, J. L., Whiffin, V. S., and van Loosdrecht, M. C. (2010). Fixation and distribution of bacterial activity in sand to induce carbonate precipitation for ground reinforcement. Ecol. Engin. 36, 112-117. doi: 10.1016/j.ecoleng.2009.01.004

Ivanov, V., and Chu, J. (2008). Applications of microorganisms to geotechnical engineering for bioclogging and biocementation of soil in situ. Rev. Environ. Sci. Biotechnol. 7, 139-153. doi: 10.1007/s11157-007-9126-3

Li, M., Fu, Q., Zhang, Q., Achal, V., and Kawasaki S. (2015). Bio-grout based on microbially induced sand solidification by means of asparaginase activity. Sci. Rep. 5:16128. doi: 10.1038/srep16128

Mann, S. (1993). Molecular tectonics in biomineralization and biomimetic materials chemistry. Nature 365, 499-505. doi: 10.1038/365499a0 
Rong, H., Qian, C.-X., and Li, L.-Z. (2012). Study on microstructure and properties of sandstone cemented by microbe cement. Const. Build. Mater. 36, 687-694. doi: 10.1016/j.conbuildmat.2012.06.063

van Paassen, L. A., Harkes, M. P., van Zwieten, G. A., van der Zon, W. H., van der Star, W. R. L., and van Loosdrecht, M. C. M. (2009). "Scale up of Biogrout: a biological ground reinforcement method," in Proceedings of the 17th International Conference on Soil Mechanics and Geotechnical Engineering, eds M. Hamza, M. Shahien, and Y. E. Mossallamy (Alexandria), $2328-2333$.

van Wijngaarden, W. K., Vermolen, F. J., van Meurs, G. A. M., and Vuik, C. (2011). Modelling biogrout: a new ground improvement method based on microbial-induced carbonate precipitation. Transp. Porous Med. 87, 397-420. doi: 10.1007/s11242-010-
Whiffin, V. S., van Paassen, L. A., and Harkes, M. P. (2007). Microbial carbonate precipitation as a soil improvement technique. Geomicrobiol. J. 24, 417-423. doi: 10.1080/01490450701436505

Conflict of Interest Statement: The authors declare that the research was conducted in the absence of any commercial or financial relationships that could be construed as a potential conflict of interest.

Copyright $\odot 2016$ Achal and Kawasaki. This is an open-access article distributed under the terms of the Creative Commons Attribution License (CC BY). The use, distribution or reproduction in other forums is permitted, provided the original author(s) or licensor are credited and that the original publication in this journal is cited, in accordance with accepted academic practice. No use, distribution or reproduction is permitted which does not comply with these terms. 